PYTHAGORAS: Jurnal Pendidikan Matematika

Volume 11 - Nomor 2, Desember 2016, (193-206)

Available online at: http://journal.uny.ac.id/index.php/pythagoras

\title{
Kemampuan Representasi dan Komunikasi Matematis Peserta Didik SMA Ditinjau dari Prestasi Belajar dan Gaya Kognitif
}

\section{Ranisa Junita}

Universitas Jambi. Jl. Lintas Jambi - Muara Bulian Km. 15, Mendalo Darat, Jambi 36122, Indonesia Korespondensi Penulis. Email: ranisaita@gmail.com

\begin{abstract}
Abstrak
Penelitian ini bertujuan untuk mendeskripsikan dan membandingkan kemampuan representasi dan komunikasi matematis ditinjau dari prestasi belajar dan gaya kognitif. Jenis penelitian yang digunakan adalah quasi eksperimen dengan desain ex post facto. Data dianalisis menggunakan uji multivariat Hotelling's Trace $\left(\mathrm{T}^{2}\right)$ dan uji univariat $t$-Bonferroni. Hasil penelitian menunjukkan tidak terdapat interaksi prestasi belajar dan gaya kognitif yang membedakan representasi dan komunikasi matematis. Peserta didik field independent lebih baik dalam kemampuan representasi dan komunikasi matematis dibandingkan peserta didik field dependent, dan tingkat prestasi belajar membedakan kemampuan representasi dan komunikasi matematis.

Kata Kunci: representasi matematis, komunikasi matematis, prestasi belajar, dan gaya kognitif

\section{Mathematical Representation and Communication Ability of Senior High School Students in Terms of Learning Achievement and Cognitive Style}

Abstract

This study aimed to describe mathematical and compare mathematical representation and communication ability in terms of learning achievement and cognitive style. Type of this study was quasi eksperimen by ex post facto design. Data were analyzed using multivariate Hotteling's Trace $\left(T^{2}\right)$ and univariate t-Bonfferoni. The result of this study show that there was no interaction between learning achievement and cognitive style in that different mathematical representation and communication ability. Students with field independent cognitive style have better mathematical representation ability and mathematical communication ability than students with field dependent cognitive style and the level of learning achievement differentiate between mathematical representation and communication ability.
\end{abstract}

Keywords: mathematical representation, mathematical communication, learning achievement, and cognitive style

How to Cite: Junita, R. (2016). Kemampuan representasi dan komunikasi matematis peserta didik SMA ditinjau dari prestasi belajar dan gaya kognitif. PYTHAGORAS: Jurnal Pendidikan Matematika, 11(2), 193-206. doi:http://dx.doi.org/10.21831/pg.v11i2.10655

Permalink/DOI: http://dx.doi.org/10.21831/pg.v11i2.10655 


\section{PENDAHULUAN}

Indonesia diharapkan mampu meraih keunggulan dalam persaingan global (Renstra Ditjen Dikmen, 2012, pp.25-26). Bagaimanapun sistem pendidikan Indonesia diselenggarakan akan menghasilkan lulusan yang mampu mewujudkan harapan tersebut. Persaingan bangsa secara nasional ataupun internasional tidak dapat dielakkan karena seiring dengan perkembangan pesat ilmu pengetahuan dan teknologi, serta kemajuan ekonomi. Hasil pendidikan dan pembelajaran sekolah akan menjadi cerminan masa yang akan datang.

Renstra Ditjen Dikmen (2012, p.4) memprediksi komposisi tenaga kerja Indonesia pada 2025 akan lebih didominasi oleh lulusan Sekolah Menengah Atas (SMA) dan Sekolah Menengah Kejuruan (SMK). Renstra Ditjen Dikmen (2012, p.5) juga menyatakan lebih dari separuh lulusan pendidikan menengah (SMA, SMK, dan Madrasah Aliyah) tidak melanjutkan pendidikan ke perguruan tinggi. Kedua pernyataan tersebut mengisyaratkan meningkatnya para lulusan sekolah menengah yang langsung mengaplikasikan hasil pendidikan yang diperoleh selama masa sekolah.

Sehubungan dengan tuntutan pendidikan secara umum, pendidikan matematika sekolah di Indonesia selalu mengupayakan ketercapaian peningkatan kemampuan matematis bagi peserta didik. Fakta yang terjadi saat ini, jika dilihat dari hasil TIMSS dan PISA sejak pertama kali Indonesia ikut serta menunjukkan prestasi belajar matematika belum mampu mencapai keunggulan dalam persaingan global. Secara nasional dari hasil Ujian Nasional (UN) Matematika 3 tahun terakhir Indonesia mengalami penurunan nilai rata-rata UN nasional. Ketercapaian peningkatan kemampuan matematis yang diupayakan guna memenuhi tuntutan pendidikan secara umum masih belum menunjukkan hasil yang memuaskan. Dengan kata lain, secara lebih eksplisit prestasi belajar matematika di Indonesia masih rendah yang didukung belum tercapainya kemampuan matematis sebagai penyebab utama faktor kelemahan peserta didik ketika mengikuti TIMSS dan PISA. Seperti yang disampaikan oleh Tjalla (2011, p.14) bahwa kemampuan matematika peserta didik masih rendah dalam hal algoritma, menginterpretasi data, langkahlangkah dalam menyelesaikan masalah, dan temuan dalam bidang matematika.

Pembelajaran matematika tidak hanya menuntut peserta didik menunjukkan hasil bel- ajar yang baik tetapi menunjukkan proses konstruksi pengetahuan yang terjadi. Proses konstruksi pengetahuan yang dimaksud adalah proses penyelesaian masalah, pemahaman matematis, dan berpikir matematis. Pembelajaran matematika merupakan proses konstruksi pengetahuan yang akan terus terjadi sampai ke jenjang yang lebih tinggi. Dengan memperhatikan hal tersebut seperti yang dikutip dari Gagne (Hwang, 2007, p.191) beberapa peneliti menitikberatkan kemampuan representasi matematis peserta didik yang baik adalah kunci untuk kesuksesan penyelesaian masalah matematis. Selanjutnya, Huggins \& Maiste (1999, p.6) mengatakan bahwa untuk meningkatkan pemahaman konseptual matematis, peserta didik bisa melakukannya dengan mengemukakan ide-ide matematisnya kepada orang lain. Peserta didik yang mengemukakan ide-ide matematis dapat terlihat bagaimana peserta didik telah memahami konsep matematika. Sehingga perlu menjadi perhatian para guru untuk mengetahui pemahaman peserta didik terhadap kompetensi matematika yang sedang dipelajarinya.

Hwang (2007, p.192) mengatakan dalam ilmu psikologi, representasi berarti pemodelan hal-hal konkret dalam dunia nyata ke dalam konsep atau simbol abstrak. Selaras dengan yang diungkapkan Davis, et al. (Janvier, 1987, p.32) menyatakan bahwa sebuah representasi dapat berupa kombinasi dari sesuatu yang tertulis di atas kertas, sesuatu yang eksis dalam bentuk objek fisik dan susunan ide-ide yang terkontruksi di dalam pikiran seseorang. Kalathil \& Sherin (2000, p.27) menyatakan representations can be thought of as externalizations of students' mental models that can be manipulated, and used as shared information. Representasi dapat dianggap sebagai eksternalisasi model mental peserta didik yang dapat dimanipulasi, dan digunakan sebagai informasi bersama. Dengan lebih sederhana bahwa segala sesuatu yang dibuat peserta didik untuk mengeksternalisasikan dan memperlihatkan kerjanya disebut representasi. Dalam pengertian yang paling umum, $a$ representation is a configuration that can represent something else in some manner. Representasi adalah suatu konfigurasi yang dapat menggambarkan sesuatu yang lain dalam beberapa cara (Goldin, 2002, p.208). Sedangkan menurut Hermawati (2016, p.37) Kemampuan representasi matematis diperlukan untuk menyajikan berbagai macam gagasan-gagasan atau ideide matematis yang diterima siswa. 
Beberapa rujukan tentang pengertian representasi tersebut dapat menyimpulkan kemampuan representasi matematis. Kemampuan representasi matematis adalah kemampuan seseorang dalam menggambarkan, menuliskan, dan memodelkan gagasan kembali berupa objekobjek matematika yang telah diketahui sebelumnya dari penglihatan pada benda konkret.

Guru dapat mengkonfirmasi proses konstruksi pengetahuan yang terjadi pada peserta didik dengan komunikasi yang dilakukan antar peserta didik dan guru. Komunikasi yang dimaksud adalah proses komunikasi matematis dengan menggunakan kemampuan komunikasi matematis guru dan peserta didiknya. Brenner (Moschovich, 2010, p.6) memberikan tiga komponen kerangka komunikasi untuk matematika yaitu (1) komunikasi tentang matematika mensyaratkan kebutuhan individual untuk mendeskripsikan proses penyelesaian masalah dan pikiran mereka sendiri tentang proses ini, (2) komunikasi dalam matematika berarti menggunakan bahasa dan symbol dari konvensi matematika, 3) komunikasi dengan matematika berarti menggunakan matematika yang memberdayaan peserta didik dengan kemungkinan mereka menangani masalah berarti.

Kemampuan komunikasi menjadi salah satu kemampuan yang penting dalam pembelajaran matematika. Bahkan prestasi belajar matematika yang masih rendah berdasarkan survey TIMSS diduga terkait dengan rendahnya kemampuan komunikasi matematis siswa (Sukoco \& Mahmudi, 2016, p.12). Selai itu Sumarno (Tandiling, 2012, p.2) mengungkapkan pentingnya kemampuan komunikasi matematis didukung oleh visi pendidikan matematika yang mempunyai dua arah pengembangan yaitu memenuhi kebutuhan masa kini dan masa yang akan datang. Dengan berkomunikasi diharapkan dapat membawa peserta didik pada pemahaman yang mendalam tentang matematika dan dapat memecahkan masalah.

Pembelajaran matematika yang telah dilaksanakan dievaluasi agar diketahui ketercapaian tujuan pembelajaran yang telah ditetapkan. Evaluasi pembelajaran yang dilakukan terhadap apa yang sudah peserta didik peroleh. Sehingga hasil evaluasi yang dilaksanakan menjadi tolak ukur untuk pembelajaran matematika selanjutnya. Evaluasi yang dilakukan dapat melihat bagaimana kemampuan peserta didik dalam "bermatematika". Watson (2006, p.29) mengatakan the word "ablity" is endemic throughout mathematics education as a reason as a reason for differences in achievement, and it is used to make distinctions between learners". Kata kemampuan bersifat endemik di seluruh pendidikan matematika sebagai alasan untuk perbedaan dalam prestasi, dan digunakan untuk membuat perbedaan antara peserta didik. Dengan kata lain, kemampuan peserta didik atau kemampuan yang peserta didik peroleh menjadi tolak ukur adanya perbedaan prestasi belajar dalam kelas matematika.

Aktivitas pengajaran sering dikaitkan dengan bidang psikologi matematika. Bidang psikologi memandang baik peserta didik yang berprestasi baik maupun peserta didik yang kurang berprestasi sebagai individu yang belajar bersama-sama dalam suatu lingkungan dan memiliki perbedaan. Terkait dengan hal tersebut, perbedaan individu pada peserta didik yang mengkontruksi pengetahuannya adalah dalam memproses simbol pesan-pesan, menyimpan, dan menggunakan informasi untuk menanggapi suatu tugas. Hal sesuai dengan pendapat Wolfe \& Johnson (Oh \& Lim, 2005, p.54) yang menyatakan bahwa "individuals are different in their ways of seeking and processing information, and cognitive styles serve as relatively stable indicators of how learners perceive and interpret information, and respond to learning environments". Maksudnya adalah seseorang memiliki cara berbeda dalam mencari dan memproses informasi, serta melihat dan menginterpretasikannya. Perbedaan cara seseorang dalam memproses informasi dikenal dengan gaya kognitif, seperti yang dikatakan Keefe (Oh \& Lim, 2005, p.54) learners' cognitive styles as the information processing habits of individual learners. Gaya kognitif peserta didik sebagai kebiasaan memproses informasi pada individu peserta didik. Hal ini juga didukung oleh pernyataan Witkin (Saracho, 1997, p.4) yang mengatakan karakteristik gaya kognitif menggambarkan kecenderungan individu dalam memahami, berpikir, mengingat, menilai, dan memecahkan masalah, dan juga gaya kognitif menentukan strategi kognitif diterapkan dalam berbagai situasi. Dengan kata lain, gaya kognitif merupakan cara seseorang menggunakan kemampuan kognitifnya untuk memecahkan masalah, seperti cara seseorang memproses informasi, kemudian menyimpan dan mengkomunikasikan informasi tersebut pada saat menyelesaikan tugas.

Penelitian ini menggunakan gaya kognitif yang dikembangkan oleh Herman A. Witkin yaitu gaya kognitif field dependent dan field 
independent. Gaya Field Dependent (FD) dan Field Independent (FI) mencirikan satu dimensi persepsi, mengingat, dan berpikir setiap individu dalam hal mempersepsikan, menyimpan, mengubah, dan memproses informasi (Saracho, 1997, p.9). Witkin (Riding \& Rayer, 1998, p.38) membagi gaya kognitif atas dua gaya kognitif yaitu field dependent dan field independent. Witkin, et al. (Ruttun, 2011, p.6) menyatakan bahwa peserta didik dengan gaya kognitif field dependent dan field independent memiliki perbedaan. Menurut Witkin (Riding, 1998, p.12) peserta didik field dependent menunjukkan kebolehan lebih baik dalam pembelajaran dan dapat mengingat bahan-bahan yang mempunyai isi kandungan berkaitan dengan sosial. Kelebihan ini bergantung pada kebolehan mereka memberikan perhatian utama kepada bidang sosial. Sebaliknya prestasi individu field independent tidak berapa baik tentang bahanbahan yang berbentuk sosial karena mereka kurang memberikan perhatian kepada bahan berbentuk sosial. Selanjutnya Ruttun (2011, p.29) mengatakan "field independent learners experiences fewer navigation/disorientation problems and performs well in learning tass; in contrast, field dependent learners experience more navigation/disorientation probems and in turn perform less well in learning tasks. Peserta didik field independent mengalami masalah navigasi/disorientasi lebih sedikit dan kinerja yang baik dalam tugas-tugas belajar, sebaliknya, peserta didik field dependent mengalami lebih banyak masalah navigasi/disorientasi dan melakukan tugas-tugas belajar yang kurang baik. Implikasi gaya kognitif berdasarkan perbedaan psikologis pada peserta didik dalam pembelajaran menurut Thomas (Ardana, 2008, p.10) adalah sebagai berikut: (1) peserta didik yang memiliki gaya kognitif FD cenderung memilih belajar dalam kelompok, sesering mungkin berinteraksi dengan guru, dan memerlukan penguatan yang bersifat ekstrinsik; (2) peserta didik yang memiliki gaya kognitif FI cenderung memilih belajar individual, merespon dengan baik, dan independen. Disamping itu, mereka dapat mencapai tujuan dengan motivasi intrinsik.

Berdasarkan uraian permasalahan berikut teorinya maka dalam penelitian ini bertujuan untuk mendeskripsikan dan membandingkan kemampuan representasi dan komunikasi matematis ditinjau dari prestasi belajar dan gaya kognitif. Adapun yang menjadi hipotesis penelitian yaitu sebagai berikut: (1) terdapat interaksi antara gaya kognitif prestasi belajar yang membedakan kemampuan representasi dan komunikasi matematis; (2) peserta didik dengan gaya kognitif field independent lebih baik dalam kemampuan representasi matematis dibandingkan peserta didik dengan gaya kognitif field dependen; (3) peserta didik dengan gaya kognitif field independent lebih baik dalam kemampuan komunikasi matematis dibandingkan peserta didik dengan gaya kognitif field dependent; (4) tingkat prestasi belajar membedakan kemampuan representasi dan komunikasi matematis.

\section{METODE}

Jenis penelitian ini termasuk dalam penelitian quasi eksperimen dengan desain $e x$ post facto. Penelitian ini menggunakan pendekatan kuantitatif dan kualitatif. Penelitian dilakukan di SMA Negeri 7, 8, dan 11 Yogyakarta. Tempat uji coba instrumen dilakukan di SMA Negeri 10 Yogyakarta. Adapun waktu penelitiannya mulai dari bulan April sampai dengan Juni tahun 2014.

Populasi pada penelitian ini adalah peserta didik kelas X SMA Negeri di Yogyakarta. Sekolah tempat penelitian dipilih berdasarkan tingkat strata Sekolah Menengah Negeri Yogyakarta dari nilai ujian nasional matematika. Setelah diperoleh sekolah yang mewakili strata sekolah di Yogyakarta, sampel kelas X dipilih dengan cara pemberian tes gaya kognitif yaitu the Group Embedded Figures Test (GEFT) dan pendataan prestasi belajar matematika peserta didik berdasarkan hasil ujian tengah semester II. Melalui GEFT terpilih kelompok peserta didik yang bergaya kognitif field dependent dan peserta didik yang bergaya kognitif field independent. Hasil ujian tengah semeseter II memperoleh kelompok peserta didik yang berprestasi tinggi, sedang, dan rendah. Sampel yang diperoleh dari hasil GEFT dan hasil ujian tengah semester II digabungkan sehingga diperoleh kelompok peserta didik field dependent dengan prestasi belajar tinggi, sedang, dan rendah serta kelompok peserta didik field independent dengan prestasi belajar tinggi, sedang, dan rendah.

Prosedur yang digunakan dalam penelitian ini dimulai dengan pemberian tes gaya kognitif yaitu GEFT dan mencatat prestasi belajar matematika peserta didik melalui ujian akhir semester II. Keduanya diperlukan untuk menyaring sampel penelitian. Selanjutnya seluruh sampel penelitian diberikan tes kemampuan 
matematis yaitu tes kemampuan representasi dan komunikasi matematis. Setelah itu data dianalisis secara deskriptif dan inferensial. Prosedur penelitian ini digambarkan pada diagram seperti pada Gambar 1.

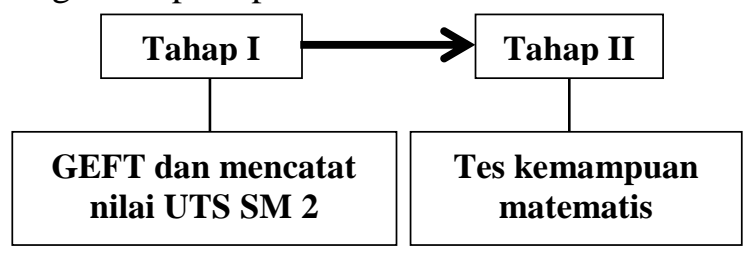

Gambar 1. Diagram Alur Penelitian

Keterangan:

$\begin{array}{ll}\text { GEFT } & \text { UTS SM 2 Groupt Embbed Figure Test } \\ \longrightarrow & \begin{array}{l}\text { :Ujian Tengah Semester } 2 \\ \text { :berlanjut ke proses selanjutnya } \\ \text { : merupakan bagian dari suatu } \\ \text { tahapan }\end{array}\end{array}$

\section{Data, Intrumen, dan Teknik Pengumpulan} Data

Data yang berasal dari hasil validasi ahli dan uji coba instrument dikumpulkan untuk memperoleh data kevalidan instrument yang digunakan. Setelah instrument dinyatakan valid dan reliable. Instrument digunakan ke lapangan guna memperoleh data kemampuan representasi dan komunikasi matematis berupa data kuantitatif dan kualitatif.

Tehnik pengumpulan data pada penelitian ini dengan cara tes tulis. Data yang diperoleh merupakan data kualitatif dan kuantitatif. Subjek diberikan 3 tes yakni tes Group Embeded Figures Test (GEFT) untuk membedakan gaya kognitif peserta didik, dan 2 tes kemampuan yaitu tes kemampuan representasi dan komunikasi matematis.

Adapun teknik pengumpulan data secara rinci melalui tahapan-tahapan sebagai berikut: (1) menyusun instrumen penelitian, yaitu menyusun kisi-kisi tes kemampuan representasi dan komunikasi matematis dan rubrik penskorannya. (2) memvalidasi instrumen penelitian yang dilakukan oleh beberapa dosen matematika; (3) uji coba instrumen penelitian; (4) melakukan prasurvey dan mengajukan perizinan ke sekolah; (5) Memberikan tes gaya kognitif kepada peserta didik kelas X di ketiga sekolah; (6) mencatat nilai ujian tengah semester II untuk seluruh peserta didik kelas X di ketiga sekolah, (7) memberikan tes representasi matematis kepada peserta didik kelas X; (8) memberikan tes komunikasi matematis kepada peserta didik kelas X; (9) mengelompokkan peserta didik berdasarkan nilai ujian pertengahan semester sebagai kelompok prestasi tinggi, prestasi sedang, dan prestasi rendah; (10) mengelompokkan peserta didik ke dalam kriteria gaya kognitif yaitu peserta didik field dependent dan field independent. Kriteria ini diperoleh dari skor hasil tes gaya kognitif. Kemudian menghitung persentase peserta didik field dependent dan field independent yang diperoleh dari ketiga sekolah; (11) setiap sekolah dikelompokkan peserta didik berdasarkan peserta didik field dependent yang prestasi tinggi, sedang dan rendah dan juga peserta didik field independent yang prestasi tinggi, sedang dan rendah; (12) setelah diperoleh kelompok-kelompok peserta didik seperti pada point 11 . Selanjutnya, mengelompokkan skor kemampuan representasi matematis dan kemampuan komunikasi matematis sesuai dengan gaya kognitif dan prestasi belajar peserta didik; dan (13) menganalisis data.

Dalam penelitian ini instrument yang digunakan untuk mengumpulkan data yaitu: (1) Tes gaya kognitif peserta didik dengan the group embedded figures test (GEFT). Tes ini digunakan untuk memperoleh data gaya kognitif peserta didik yaitu gaya kognitif field dependent dan field independent. Instrumen ini terdiri atas tiga kelompok soal, kelompok soal pertama terdiri atas 7 butir soal, kelompok soal kedua dan ketiga masing-masing terdiri atas 9 butir soal. Kelompok soal pertama tidak diberi skor karena kelompok soal ini dimaksudkan sebagai latihan bagi peserta didik dan untuk mengetahui apakah peserta didik sudah memahami perintah dan cara kerja dalam tes tersebut. Sedangkan tes sesungguhnya yang diberikan skor adalah kelompok soal kedua dan ketiga. Peserta didik diberi skor 1 jika menjawab benar dan skor 0 jika menjawab salah. Skor tertinggi yang dapat diperoleh oleh responden adalah 18. Waktu yang diberikan untuk kelompok pertama adalah 2 menit dan untuk kelompok kedua dan ketiga masing-masing 5 menit. Tugas peserta didik dalam tes ini adalah mempertebal gambar bentuk bangun datar yang sederhana dan yang terdapat di dalam gambar-gambar bangun datar yang lebih rumit untuk masing- masing soal; (2) tes kemampuan representasi matematis dan kemampuan komunikasi matematis. Tes kemampuan representasi dan komunikasi matematis yang digunakan adalah soal-soal matematika dengan bentuk soal non rutin. Dalam penelitian ini akan dikembangkan soal-soal non rutin untuk kemampuan representasi dan 
komunikasi matematis berdasarkan kompetensi geometri (dimensi tiga) kelas X.

Instumen ini dikembangkan dari SK/KI dan KD kelas X. Dalam penyusunannya diawali dengan penyusunan kisi-kisi yang mencakup kompetensi dasar, indikator, aspek yang diukur, dan rubrik penskoran. Setelah membuat kisi-kisi soal dilanjutkan dengan menyusun soal beserta kunci jawabannya dan aturan pemberian skor untuk masing-masing butir soal.

Bahan instrumen ini diambil dari kompetensi matematika SMA kelas $\mathrm{X}$ semester genap yaitu dimensi tiga. Penyusunan intrumen ini memperhatikan standar kompetensi, aspek komunikasi matematis, kemampuan representasi, dan cakupan kompetensi yang diterima peserta didik.

\section{Teknik Analisis Data}

Dalam penelitian ini, data yang dikumpulkan untuk dianalisis adalah nilai ujian tengah semester II peserta didik, skor GEFT, data hasil tes kemampuan representasi matematis, dan hasil tes kemampuan komunikasi matematis. Data ini akan dianalisis secara deskriptif kuantitatif dan deskriptif kualitatif untuk memberikan gambaran realitas dan sistematis tentang kemampuan representasi matematis dan kemampuan komunikasi matematis peserta didik.

Analisis Deskriptif

Analisis deskriptif digunakan untuk menyajikan data yang telah diperoleh dari hasil ujian tengah semester II, skor GEFT, tes kemampuan representasi dan komunikasi matematis.

Statistik deskriptif biasanya digunakan untuk menggambarkan dua sifat yaitu kecenderungan memusat dan variabilitas. Kecenderungan memusat dari distribusi skor menunjukkan dimana distribusi skor memusat, dan variabilitas menunjukkan sejauh mana skor tersebut bervariasi.

Pedoman penskoran dikonversi menjadi nilai standar (Glass \& Hopkins, 1984, p.67). Pedoman konversi yang digunakan berskala-5 berarti membagi nilai standar menjadi lima skala. Cara menyusun skala-5 dengan membagi wilayah di bawah lengkung kurva normal menjadi lima daerah. Kurva normal terbagi atas lima daerah dan setiap daerah menunjukkan kualifikasi atau nilainya. Berdasarkan pembagian daerah tersebut pedoman konversi yang disusun seperti pada Tabel 1 (Azwar, 1996, p.163).
Tabel 1. Konversi Penskoran menjadi Kategori

\begin{tabular}{ccc}
\hline No. & Rentang skor & Kategori \\
\hline 1 & $\mathrm{M}+1,5 \mathrm{Sdi}<\mathrm{X} \leq \mathrm{M}+3 \mathrm{Sdi}$ & sangat tinggi \\
2 & $\mathrm{M}+0,5 \mathrm{Sdi}<\mathrm{X} \leq \mathrm{M}+1,5 \mathrm{Sdi}$ & tinggi \\
3 & $\mathrm{M}-0,5 \mathrm{Sdi}<\mathrm{X} \leq \mathrm{M}+0,5 \mathrm{Sdi}$ & sedang \\
4 & $\mathrm{M}-1,5 \mathrm{Sdi}<\mathrm{X} \leq \mathrm{M}-0,5 \mathrm{Sdi}$ & rendah \\
5 & $\mathrm{M}-3 \mathrm{Sdi} \leq \mathrm{X} \leq \mathrm{M}-1,5 \mathrm{Sdi}$ & sangat rendah \\
\hline
\end{tabular}

Keterangan:

$\mathrm{M}=$ mean ideal

$=1 / 2($ skor maksimum + skor minimum $)$

Sdi $=$ Standar deviasi ideal

$=($ skor maksimum - skor minimum $) / 6$

$\mathrm{X}=$ skor perolehan

\section{Deskripsi Hasil Tes Gaya Kognitif}

Gaya kognitif peserta didik dilakukan menggunakan instrumen yang dikembangkan oleh Herman A. Witkin yaitu Group Embedded Figure Test (GEFT). Data yang diperoleh akan dianalisis sebagai berikut setiap jawaban benar pada bagian II dan III akan diberikan skor setiap item 1. Skor maksimum tes ini adalah 18. Kriteria gaya kognitif peserta didik menurut Ibrahim et al. (2004, p.29) seperti pada Tabel 2.

Tabel 2. Kriteria Gaya Kognitif

\begin{tabular}{lc}
\hline \multicolumn{1}{c}{ Gaya Kognitif } & Skor GEFT \\
\hline Field Dependent (FD) & $0-6$ \\
Intermediate & $7-12$ \\
Field Independent (FI) & $13-18$ \\
\hline \multicolumn{2}{c}{ Sumber: Ibrahim, et al. (2004, p.29) }
\end{tabular}

Deskripsi Hasil Ujian Tengah Semester II Peserta Didik Kelas X

Data ujian tengah semester II digunakan untuk menentukan peserta didik yang berpretasi tinggi, sedang, dan rendah. Penentuan tingkat prestasi ini berdasarkan rata-rata, dan standar deviasi setiap sekolah yang dirumuskan seperti pada tabel 3. Deskripsi hasil ujian tengah semester II dideskripsikan dari persentasi kelulusan yaitu lebih besar sama dengan 75 (KKM $\geq 75$ ), nilai rata-rata, standar deviasi, variansi, nilai tertinggi, nilai terendah, nilai maksimum, dan nilai minimum setiap sekolah. Selanjutnya data dikonversi menjadi kriteria kualitatif yang menyatakan kualitas yang diperoleh setiap sekolah berdasarkan hasil ujian tengah semester II. Berdasarkan pembagian daerah pedoman konversi dilakukan modifikasi menjadi 3 kriteria (Direktorat pembinaan SMA, 2010, p.59), seperti pada Tabel 3. 
Tabel 3. Kriteria Prestasi Belajar Matematika Peserta Didik

\begin{tabular}{ccc}
\hline No. & \multicolumn{1}{c}{ Formula } & $\begin{array}{c}\text { Kriteria Prestasi } \\
\text { Belajar Matematika }\end{array}$ \\
\hline 1 & $(\mathrm{M}+\mathrm{Sd}) \leq \mathrm{X}$ & Tinggi $(\mathrm{t})$ \\
2 & $(\mathrm{M}+\mathrm{Sd}) \leq \mathrm{X}<(\mathrm{M}-\mathrm{Sd})$ & Sedang $(\mathrm{s})$ \\
$3 \quad \mathrm{X}<(\mathrm{M}-\mathrm{Sd})$ & Rendah $(\mathrm{r})$ \\
\hline \multicolumn{2}{c}{ Sumber: Direktorat Pembinaan SMA, 2010, $\mathrm{p} .59$} \\
Keterangan: \\
$\mathrm{X} \quad=$ nilai matematika pada ujian tengah \\
$\mathrm{M} \quad$ semester II \\
$\mathrm{Sd}=$ Mean (rata-rata) \\
Destandar Deviasi \\
Matematis
\end{tabular}

Penentuan skor tes kemampuan representasi matematis berdasarkan rubrik pedoman penskoran tes kemampuan representasi matematis. Melalui pedoman penskoran tes kemampuan representasi diperoleh nilai maksimum seluruh item 24 dan nilai minimumnya adalah 0 . Tabel 4 berikut menunjukkan kriteria kemampuan representasi matematis.

Tabel 4. Kriteria Kemampuan Representasi Matematis

\begin{tabular}{|c|c|c|}
\hline No. & Formula & $\begin{array}{c}\text { Kriteria Kemampuan } \\
\text { Representasi Matematis }\end{array}$ \\
\hline 1 & $18 \leq X$ & Baik sekali \\
\hline 2 & $\begin{array}{l}14 \leq X< \\
18\end{array}$ & Baik \\
\hline 3 & $\begin{array}{l}10 \leq X< \\
14\end{array}$ & Sedang \\
\hline 4 & $\begin{array}{l}6 \leq X< \\
10\end{array}$ & Kurang \\
\hline 5 & $x<6$ & Sangat kurang \\
\hline
\end{tabular}

Sumber: Azwar, 1996, p.163

Keterangan:

$\mathrm{X}=$ skor kemampuan representasi matematis

$$
\begin{aligned}
\mathrm{Mi} & =\text { mean }(\text { rata-rata) skor ideal } \\
& =(24+0) / 2=12 \\
\mathrm{Sdi} & =\text { standar deviasi skor ideal } \\
& =(24-0) / 6=4
\end{aligned}
$$

Deskripsi Tes Kemampuan Komunikasi Matematis

Penentuan skor setiap item tes kemampuan komunikasi matematis berdasarkan rubrik penskoran tes kemampuan komunikasi mate- matis. Melalui pedoman penskoran tes kemampuan komunikasi diperoleh nilai maksimum seluruh item 27 dan nilai minimumnya adalah 0 . Tabel 5 berikut menunjukkan kriteria kemampuan komunikasi matematis.

Tabel 5. Kriteria Kemampuan Komunikasi Matematis

\begin{tabular}{ccc}
\hline No. & Formula & $\begin{array}{c}\text { Kriteria Kemampuan } \\
\text { Representasi Matematis }\end{array}$ \\
\hline 1 & $20,25 \leq \mathrm{X}$ & Baik sekali \\
2 & $15,75 \leq \mathrm{X}<20,25$ & Baik \\
3 & $11,25 \leq \mathrm{X}<15,75$ & Sedang \\
4 & $6,75 \leq \mathrm{X}<11,25$ & Kurang \\
5 & $\mathrm{X}<6,75$ & Sangat kurang \\
\hline \multicolumn{2}{c}{ Sumber: Azwar, 1996, p.163 }
\end{tabular}

Ket.:

$\mathrm{X}=$ skor kemampuan komunikasi matematis

$\mathrm{Mi}=$ mean (rata-rata) skor ideal $=(27+0) / 2=13,5$

$\mathrm{Sdi}=$ standar deviasi skor ideal $=(27-0) / 6=4,5$

Analisis Inferensial Uji Asumsi

Uji normalitas yang digunakan dengan menggunakan uji jarak mahalanobis. Adapaun kritera yang digunakan adalah jika sekitar 50\% data mempunyai nilai $d j^{2}<\chi^{2}$ (jarak-kuadrat kurang dari chi-kuadrat) maka data berdistribusi normal (Johson \& Wichern, 2007, p.186).

Tahapan untuk melakukan uji ini adalah sebagai berikut; (a) menentukan nilai vektor rata-rata $(\bar{x})$ dan invers matriks varians kovarians $\left(S^{-1}\right)$; (b) menentukan nilai $d_{i}^{2}$ yang merupakan jarak mahalanobis setiap pengamatan dengan formula sebagai berikut $d_{i}^{2}=\left(X_{i}-\bar{X}\right)^{t} S^{-1}\left(X_{i}-\bar{X}\right) \quad$ dengan $i=1,2, \ldots, n$; (c) mengurutkan $d_{i}^{2}$ dari yang terkecil sampai dengan yang terbesar untuk kemudian membandingkan nilainya dengan $\chi_{(p ; 0,5)}^{2}$. Tabel 6 menyajikan banyak $d j^{2}<\chi^{2}$ untuk masing-masing kelompok.

Berdasarkan Tabel 6, tampak bahwa untuk semua kelompok memiliki persentase jumlah $d j^{2}<\chi^{2}$ di sekitar 50\%. Dengan kata lain, asumsi normalitas multivariat untuk data kemampuan representasi dan komunikasi matematis terpenuhi. 
Tabel 6. Persentase Banyak $d j^{2}<\chi^{2}$ untuk Data Kemampuan representasi dan Komunikasi Matematis

\begin{tabular}{clcccc}
\hline \multirow{2}{*}{ Gaya Kognitif } & Tingkat Prestasi & \multicolumn{3}{c}{ Hasil Perhitungan } & \multirow{2}{*}{ Ket. } \\
\cline { 3 - 5 } & & Banyak Peserta didik & $\begin{array}{c}\text { Banyak } \\
\boldsymbol{d j}^{2}<\chi^{2}\end{array}$ & $\%$ & \\
\hline \multirow{2}{*}{ FD } & Rendah & 28 & 14 & $50,00 \%$ & normal \\
& Sedang & 80 & 39 & $48,75 \%$ & normal \\
& Tinggi & 30 & 15 & $50,00 \%$ & normal \\
& Rendah & 26 & 13 & $50,00 \%$ & normal \\
\multirow{2}{*}{ FI } & Sedang & 73 & 38 & $52,06 \%$ & normal \\
& Tinggi & 27 & 15 & $55,56 \%$ & normal \\
\hline
\end{tabular}

Ket.: $d j^{2}=$ jarak-kuadrat

$\chi^{2}=$ chi-kuadrat

Uji homogenitas dilakukan melalui uji homogenitas Box's M Test. Uji ini dilakukan karena terdapat dua variabel dependent (Ghozali, 2009, p.80). Perhitungan uji homogenitas dilakukan dengan bantuan software SPSS 21.0 for windows, dengan hipotesis sebagai berikut.

$\mathrm{H}_{\mathrm{o}} \quad$ : matriks kovarians dari variabel dependen adalah sama

$\mathrm{H}_{1} \quad$ : matriks kovarians dari variabel dependen adalah tidak sama

Kriteria pengujian adalah $\mathrm{H}_{\mathrm{o}}$ ditolak jika nilai signifikansi $<\alpha$. Perhitungan menggunakan SPSS 21.0 for windows pada taraf signifikansi 5\%. Hasilnya disajikan pada Tabel 7.

Tabel 7. Hasil uji Homogenitas Kovarian Matriks

\begin{tabular}{ccccc}
\hline Box's M & $\mathrm{F}$ & $\mathrm{df}_{1}$ & $\mathrm{df}_{2}$ & Sig. \\
\hline 2,575 & 0,851 & 3 & 16784370,42 & 0,466 \\
\hline
\end{tabular}

Tabel 7 menunjukkan bahwa nilai signifikansi pengukuran $>0,05$ maka $\mathrm{H}_{\mathrm{o}}$ tidak dapat ditolak, artinya matriks kovarians dari variabel dependen hasil pengukuran kemampuan representasi dan komunikasi matematis adalah sama.

\section{Uji Hipotesis}

Pada penelitian ini uji multivariat yang digunakan adalah $T^{2}$ Hotelling dengan taraf signifikansi $\alpha=0,05$. Rumus $T^{2}$ Hotelling adalah sebagai berikut:

$$
T^{2}=\frac{n_{1} n_{2}}{n_{1}+n_{2}}\left(\overline{Y_{1}}-\bar{Y}_{2}\right)^{\prime} S^{-1}\left(\bar{Y}_{1}-\bar{Y}_{2}\right)
$$

Keterangan:

$n_{1} \quad$ : banyak peserta didik kelompok 1

$n_{2} \quad$ : banyak peserta didik kelompok 2

$\overline{Y_{1}}-\overline{Y_{2}}:$ selisih mean vektor

$S^{-1} \quad$ : invers, matriks konvarians

(Steven, 2009, p.148)
Setelah diperoleh nilai $T^{2}$ Hotelling, selanjutnya dihitung distribusi $\mathrm{F}$ dengan rumus sebagai berikut:

$$
F=\frac{n_{1}+n_{2}-p-1}{p\left(n_{1}+n_{2}-2\right)} T^{2}
$$

dengan $\mathrm{p}$ adalah banyaknya variabel terikat., (Steven, 2009, p.148)

Selanjutnya nilai distribusi $F$ yang diperoleh dikonstrukskan pada nilai $\mathrm{F}_{0,05(\mathrm{p} ; n 1+n 2-\mathrm{p}-}$ 1) untuk mengambil keputusan kriteria keputusan yang digunakan untuk uji hipotesis ini adalah $\mathrm{H}_{0}$ ditolak jika $F_{\text {hit }}>F_{(p ; n 1+n 2-p-1)}$

Mengacu pada hasil uji multivariat, jika uji tersebut menunjukkan bahwa $\mathrm{H}_{0}$ gagal ditolak maka analisis data dilanjutkan dengan uji univariat yaitu uji t dengan kriteria Bonferroni, dengan taraf signifikansi $\alpha / p(p=2)$. Rumus uji t yang digunakan adalah

$$
t=\frac{P_{1}-P_{2}}{\sqrt{\frac{\left(n_{1}-1\right) S_{1}^{2}+\left(n_{2}-1\right) S_{2}^{2}}{n_{1}+n_{2}-2}\left(\frac{1}{n_{1}}+\frac{1}{n_{2}}\right)}} \text { (Steven, 2009, }
$$

p.147)

Keterangan:

$\bar{Y}_{1}=$ rata-rata kelompok 1

$\overline{Y_{2}}=$ rata-rata kelompok 2

$n_{1}=$ banyak sampel dari kelompok 1

$n_{2}=$ banyak sampel dari kelompok 2

$S_{1}^{2}=$ varian sampel kelompok 1

$S_{2}^{2}=$ varian sampel kelompok 2 .

Kriteria keputusan yang digunakan adalah $\mathrm{H}_{0}$ ditolak. Jika $\mathrm{t}_{\text {hitung }}>\mathrm{t}_{\text {tabel }}=t_{\left(\frac{0,05}{p} ; n_{1}+n_{2}-4\right)}$. Pengujian dilakukan dengan Microsoft Excell.

\section{HASIL DAN PEMBAHASAN}

Hasil penelitian ini adalah sebagai berikut

\section{Distribusi Gaya Kognitif}

Gaya kognitif pada penelitian ini adalah field dependent dan field independent. Setelah dilakukan tes dan diberi skor diperoleh gaya 
kognitif peserta didik. Setiap sekolah memiliki pensebaran yang berbeda. Sehingga Tabel 8 berikut menampilkan frekuensi pensebaran gaya kognitif di setiap sekolah.

Tabel 8. Distribusi Frekuensi Gaya Kognitif Peserta Didik

\begin{tabular}{|c|c|c|c|c|c|c|c|}
\hline \multirow{2}{*}{ Skor } & \multirow{2}{*}{ Kategori } & \multicolumn{2}{|c|}{$\begin{array}{l}\text { SMA N } \\
8\end{array}$} & \multicolumn{2}{|c|}{$\begin{array}{c}\text { SMA N } \\
7\end{array}$} & \multicolumn{2}{|c|}{$\begin{array}{c}\text { SMA N } \\
11\end{array}$} \\
\hline & & $\mathbf{f}$ & $\%$ & f & $\%$ & f & $\%$ \\
\hline $0-6$ & field & 34 & 18,58 & 46 & 28,57 & 76 & 29,12 \\
\hline $7-12$ & Intermediate & 87 & 47,54 & 82 & 50,93 & 133 & 50,96 \\
\hline $\begin{array}{c}13- \\
18\end{array}$ & $\begin{array}{l}\text { field } \\
\text { independent }\end{array}$ & 62 & 3,88 & 33 & 20,50 & 52 & 19,92 \\
\hline
\end{tabular}

Tabel 8 menunjukkan pada SMA Negeri 8 Yogyakarta peserta didik yang berkategori field independent lebih banyak dari pada kategori field dependent, 34 peserta didik $(18,58 \%)$ berkategori field dependent dan 62 peserta didik $(33,88 \%)$ berkategori field independent. Pada SMA Negeri 7 peserta didik yang berkategori field dependent lebih banyak dari pada field independent, 46 peserta didik $(28,57 \%)$ berkategori field dependent dan 33 peserta didik $(20,50 \%)$ berkategori field independent. Pada SMA Negeri 11 peserta didik yang berkategori field dependent lebih banyak dari pada field independent, 76 peserta didik $(28,57 \%)$ berkategori field dependent dan 52 peserta didik $(19,92 \%)$ berkategori field independent.

\section{Hasil Tes Kemampuan Representasi Matematis}

Hasil akhir penskoran tes kemampuan representasi setiap skor yang diperoleh sekolah dirata-rata sehingga menindentifikasikan kriteria tertentu, seperti yang telah ditetapkan sebelumnya. Tabel 9 menampilkan deskripsi hasil tes kemampuan representasi matematis di setiap sekolah.

Tabel 9. Deskripsi Hasil Tes Kemampuan Representasi Matematis

\begin{tabular}{cccc}
\hline \multirow{3}{*}{ Statistik } & \multicolumn{3}{c}{ Nama Sekolah } \\
\cline { 2 - 4 } & $\begin{array}{c}\text { SMA N 8 } \\
\text { Yogyakarta }\end{array}$ & $\begin{array}{c}\text { SMA N 7 } \\
\text { Yogyakarta }\end{array}$ & $\begin{array}{c}\text { SMA N 11 } \\
\text { Yogyakarta }\end{array}$ \\
\hline$\overline{\boldsymbol{X}}$ & 10,64 & 9,16 & 3,19 \\
$\mathrm{~S}$ & 4,77 & 4,64 & 3,27 \\
$\mathrm{~S}^{2}$ & 22,75 & 21,53 & 10,67 \\
$\mathrm{X}_{\max }$ & 24 & 24 & 24 \\
$\mathrm{X}_{\min }$ & 0 & 0 & 0 \\
$X_{\text {terendah }}$ & 16 & 23 & 11 \\
$X_{\text {tertinggi }}$ & 3 & 1 & 1 \\
\hline
\end{tabular}

Berdasarkan Tabel 9 SMA Negeri 8 Yogyakarta mendapat hasil tes kemampuan representasi matematis 10,64. Kriteria yang diperoleh untuk SMA Negeri 8 Yogyakarta adalah sedang. SMA Negeri 7 yogyakarta mendapat hasil tes 9,16 dengan kriteria kurang. Sedangkan, SMA Negeri 11 Yogyakarta mendapat kriteria sangat kurang dengan hasil tes 3,19.

Hasil Tes Kemampuan Komunikasi Matematis

Hasil yang diperoleh dari tes kemampuan komunikasi setiap sekolah menggambarkan kemampuan komunikasi yang terjadi saat ini di lingkungan sekolah. Tabel 10 menampilkan hasil penskoran tes kemampuan komunikasi matematis yang dimuat berupa deskripsi hasil tes kemampuan komunikasi matematis.

Tabel 10. Deskripsi Hasil Tes Kemampuan Komunikasi Matematis

\begin{tabular}{lccc}
\hline \multirow{3}{*}{ Statistik } & \multicolumn{3}{c}{ Nama Sekolah } \\
\cline { 2 - 4 } & $\begin{array}{c}\text { SMA N 8 } \\
\text { Yogyakarta }\end{array}$ & $\begin{array}{c}\text { SMA N 7 } \\
\text { Yogyakarta }\end{array}$ & $\begin{array}{c}\text { SMA N 11 } \\
\text { Yogyakarta }\end{array}$ \\
\hline$\overline{\boldsymbol{X}}$ & 17,85 & 15,10 & 13,19 \\
$\mathrm{~S}$ & 2,91 & 4,62 & 4,93 \\
$\mathrm{~S}^{2}$ & 8,47 & 21,34 & 24,28 \\
$\mathrm{X}_{\max }$ & 27 & 27 & 27 \\
$\mathrm{X}_{\min }$ & 0 & 0 & 0 \\
$X_{\text {terendah }}$ & 24 & 24 & 24 \\
$X_{\text {tertinggi }}$ & 7 & 4 & 7 \\
\hline
\end{tabular}

Tabel 10 menunjukkan rata-rata hasil tes kemampuan komunikasi matematis di SMA Negeri 8 Yogyakarta 17,85. Berdasarkan kriteria kemampuan komunikasi matematis 17,85 termasuk ke dalam interval baik. Sehingga SMA Negeri 8 Yogyakarta memperoleh kriteria baik dalam kemampuan komunikasi matematis. Sedangkan rata-rata hasil tes kemampuan komunikasi matematis di SMA Negeri 7 Yogyakarta adalah 15,10. Berdasarkan kriteria kemampuan komunikasi matematis yang telah ditetapkan, SMA Negeri 7 Yogyakarta termasuk kategori sedang. Sedangkan, SMA Negeri 11 Yogyakarta mempunyai rata-rata hasil tes kemampuan komunikasi matematis 13,19 dan skor ini juga termasuk berkategori sedang.

\section{Hasil Tes Kemampuan Representasi dan Komunikasi Matematis ditinjau dari prestasi belajar dan gaya kognitif}

Setelah dilakukan penskoran setiap sekolah baik untuk tes kemampuan representasi maupun komunikasi matematis. Penskoran kedua tes ini dikelompokkan berdasarkan prestasi belajar dan gaya kognitif peserta didik. Jika deskripsi sebelumnya dilakukan untuk menggambarkan kemampuan representasi dan komunikasi 
matematis yang peroleh di setiap sekolah, berikut ini akan digambarkan kemampuan matematis ini secara kelompok. Misalkan skor kemampuan representasi matematis kelompok peserta didik yang field dependent dengan prestasi belajar tinggi digabungkan dari ketiga sekolah. Tabel 11 menampilkan deskripsi hasil tes kemampuan representasi dan komunikasi matematis untuk setiap kolempok.

Setelah dilakukan deskripsi data selanjutnya akan diketahui kriteria secara kualitatif yang diperoleh setiap kelompok berdasarkan kriteria yang telah ditetapkan. Tabel 12 menampilkan kriteria hasil tes kemampuan representais dan komunikasi matematis setiap kelompoknya. Berdasarkan Tabel 12 diketahui bahwa kemampuan representasi tidak memperoleh kriteria baik di kelompok mana pun. Sedangkan kemampuan komunikasi matematis terdapat kriteria baik pada kelompok peserta didik field independent yang berprestasi tinggi dan sedang.

Langkah selanjutnya dilakukan uji hipotesis untuk mengetahui apakah terdapat interaksi prestasi belajar dan gaya kognitif yang membedakan kemampuan representasi dan komunikasi matematis. Uji yang digunakan merupakan uji multivariate dengan uji statistik T2 Hotelling's Trace. Sebelum dilakukan uji hipotesis dilakukan uji asumsi yaitu normalitas dan homogenitas. Hasilnya data penelitian ini dapat menunjukkan populasi dikatakan normal dan homogen. Hipotesis penelitian ini telah disebutkan pada bagian pendahulan sebelumnya. Tabel 13 menunjukkan hasil uji multivariate.

Tabel 11. Deskripsi Hasil Tes Kemampuan Representasi dan Komunikasi Matematis

\begin{tabular}{|c|c|c|c|c|c|c|c|}
\hline \multirow{3}{*}{ TP } & \multirow{3}{*}{ Stat. } & \multicolumn{4}{|c|}{ Gaya Kognitif } & \multirow{2}{*}{\multicolumn{2}{|c|}{ Gabungan }} \\
\hline & & \multicolumn{2}{|c|}{ Field dependent } & \multicolumn{2}{|c|}{ Field independent } & & \\
\hline & & Rep & Kom & Rep & Kom & Rep & Kom \\
\hline \multirow{6}{*}{$\mathrm{t}$} & $\mathrm{n}$ & 30 & 30 & 27 & 27 & 57 & 57 \\
\hline & $\bar{x}$ & 10,13 & 18,40 & 10,78 & 19,04 & 10,44 & 18,70 \\
\hline & $\mathrm{s}$ & 4,67 & 5,32 & 3,01 & 3,36 & 4,95 & 3,16 \\
\hline & $X_{\text {terendah }}$ & 3 & 11 & 2 & 11 & 2 & 11 \\
\hline & $X_{\text {tertinggi }}$ & 16 & 22 & 20 & 24 & 20 & 24 \\
\hline & $X_{\max }$ & 24 & 27 & 24 & 27 & 24 & 27 \\
\hline & $\mathrm{n}$ & 80 & 80 & 73 & 73 & 153 & 153 \\
\hline \multirow{5}{*}{$\mathrm{S}$} & $\bar{x}$ & 7,03 & 14,50 & 9,63 & 16,49 & 8,27 & 15,45 \\
\hline & $\mathrm{s}$ & 4,49 & 3,81 & 4,74 & 3,25 & 4,77 & 3,68 \\
\hline & $X_{\text {terendah }}$ & 1 & 7 & 1 & 7 & 1 & 7 \\
\hline & $X_{\text {tertinggi }}$ & 24 & 21 & 23 & 22 & 24 & 22 \\
\hline & $X_{\max }$ & 24 & 27 & 24 & 27 & 24 & 27 \\
\hline \multirow{6}{*}{$\mathrm{r}$} & $\mathrm{n}$ & 28 & 28 & 26 & 26 & 54 & 54 \\
\hline & $\bar{x}$ & 5,75 & 14,25 & 7,31 & 15,31 & 6,50 & 14,76 \\
\hline & $\mathrm{s}$ & 3,69 & 4,02 & 3,66 & 3,89 & 3,73 & 3,96 \\
\hline & $X_{\text {terendah }}$ & 0 & 7 & 1 & 5 & 0 & 5 \\
\hline & $\begin{array}{l}X_{\text {tererendah }} \\
X_{\text {tertinggi }}\end{array}$ & 17 & 24 & 13 & 20 & 17 & 24 \\
\hline & $X_{\max }$ & 24 & 27 & 24 & 27 & 24 & 27 \\
\hline \multirow{6}{*}{$\mathrm{g}$} & $\mathrm{n}$ & 138 & 138 & 126 & 126 & & \\
\hline & $\bar{x}$ & 7,44 & 15,29 & 9,39 & 16,79 & & \\
\hline & $\mathrm{s}$ & 4,60 & 4,02 & 4,78 & 3,61 & & \\
\hline & $X_{\text {terendanh }}$ & 0 & 7 & 1 & 5 & & \\
\hline & $\begin{array}{l}X_{\text {terendah }} \\
\text { tertingeg }^{2}\end{array}$ & 24 & 24 & 23 & 24 & & \\
\hline & $X_{\max }$ & 24 & 27 & 24 & 27 & & \\
\hline
\end{tabular}

Keterangan: stat. $=$ statistik $; \mathrm{TP}=$ tingkat prestasi $\mathrm{t}=$ tinggi $\mathrm{s}=$ sedang; dan $\mathrm{r}=$ rendah

Tabel 12. Kriteria Kemampuan Representasi dan Komunikasi Matematis

\begin{tabular}{|c|c|c|c|c|c|c|c|}
\hline \multirow{7}{*}{ 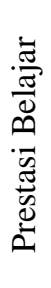 } & & \multicolumn{4}{|c|}{ Gaya Kognitif } & \multirow{2}{*}{\multicolumn{2}{|c|}{ Gab. }} \\
\hline & & \multicolumn{2}{|c|}{ FD } & \multicolumn{2}{|c|}{ FI } & & \\
\hline & & Rep & Kom & Rep & Kom & Rep & Kom \\
\hline & $\mathrm{T}$ & sedang & Baik & sedang & Baik & Sedang & baik \\
\hline & S & kurang & sedang & kurang & Baik & Kurang & baik \\
\hline & $\mathrm{R}$ & sangat kurang & sedang & kurang & Sedang & Kurang & sedang \\
\hline & Gab. & kurang & sedang & kurang & Baik & & \\
\hline
\end{tabular}


Keterangan:

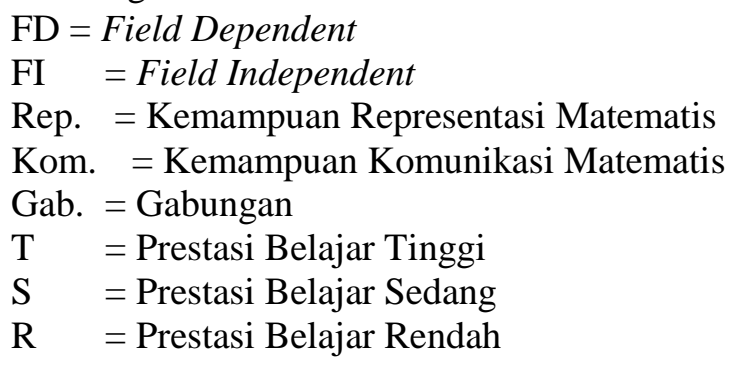

Tabel 13. Hasil Uji Multivariat

\begin{tabular}{llcc}
\hline \multicolumn{1}{c}{ Faktor } & \multicolumn{1}{c}{ Uji Statistik } & Nilai F & Sig. \\
\hline Gaya Kognitif & Hotelling's Trace & $5,580^{\mathrm{b}}$ & 0,004 \\
Prestasi & Hotelling's Trace & 13,979 & 0,000 \\
Gaya Kognitif*Prestasi & Hotelling's Trace & 0,833 & 0,504 \\
\hline
\end{tabular}

Keterangan

$\mathrm{a}=$ exact statistics

Gaya kognitif*Prestasi = interaksi gaya kognitif dan prestasi belajar matematika

Tabel 14. Hasil Uji Univariat

\begin{tabular}{ccccccc}
\hline Hip. & $\mathbf{t}_{\text {hitung }}$ & $\mathbf{n}_{\mathbf{1}}$ & $\mathbf{n}_{\mathbf{2}}$ & $\mathbf{d f}$ & $\mathbf{t}_{\text {tabel }}$ & Kes. \\
\hline $\mathrm{H}_{01}$ & $-3,39$ & 138 & 126 & 260 & 2,25 & gagal ditolak \\
$\mathrm{H}_{02}$ & $-3,17$ & 138 & 126 & 260 & 2,25 & gagal ditolak \\
$\mathrm{H}_{03}$ & 4,75 & 54 & 57 & 107 & 2,27 & ditolak \\
$\mathrm{H}_{04}$ & 3,84 & 54 & 57 & 107 & 2,27 & ditolak \\
\hline
\end{tabular}

) : hipotesis dapat dilihat pada Pendahuluan

Hasil analisis pada Tabel 13 menunjukkan interaksi gaya kognitif dan prestasi belajar mendapat nilai $F=0,8333$ dengan signifikansi 0,504 . signifikansinya lebih besar dari 0,05 . Artinya interaksi kedua faktor signifikan atau hipotesis null $\left(\mathrm{H}_{01}\right)$ ditolak dengan kata lain tidak terdapat perbedaan interaksi gaya kognitif dan prestasi belajar pada kemampuan representasi dan komunikasi matematis.

Hasil analisis selanjutnya menunjukkan bahwa harga $\mathrm{F}=5,580^{\mathrm{a}}$ untuk Hotelling's Trace gaya kognitif memiliki signifikansi 0,004. Signifikansinya lebih kecil dari 0,05 . Artinya faktor gaya kognitif tidak signifikan atau hipotesis null $\left(\mathrm{H}_{02}\right)$ gagal ditolak dengan kata lain terdapat perbedaan gaya kognitif pada kemampuan representasi dan komunikasi matematis.

Hal yang sama terjadi pada faktor prestasi belajar bahwa harga $\mathrm{F}=13,979$ dengan signifikansi 0,000. Signifikansi yang diperoleh lebih kecil dari 0,05 sehingga faktor prestasi belajar tidak signifikan atau hipotesis null $\left(\mathrm{H}_{03}\right)$ gagal ditolak dengan kata lain terdapat perbedaan prestasi belajar (tinggi, sedang, rendah) pada kemampuan representasi dan komunikasi matematis.

Uji hipotesis dilanjutkan pada uji univariat menggunakan $t$-Bonferroni. Tabel $14 \mathrm{me}$ nampilkan hasil uji univariat.
Analisis pada Tabel 14 menunjukkan pada hipotesis pertama diperoleh $\mathrm{t}_{\text {hitung }}=-3,3852$ $<\mathrm{t}_{\text {tabel }}=2,2544$ artinya hipotesis null $\left(\mathrm{H}_{01}\right)$ tidak signifikan atau hipotesis gagal ditolak. Dengan kata lain, peserta didik yang bergaya kognitif field independent memperlihatkan hasil kemampuan representasi matematis yang lebih baik dari pada peserta didik yang field dependent.

Hal ini juga terjadi pada kemampuan komunikasi, diperoleh $\mathrm{t}_{\text {hitung }}=-3,1694<\mathrm{t}_{\text {tabel }}=$ 2,2544 artinya hipotesis null $\left(\mathrm{H}_{02}\right)$ tidak signifikan atau hipotesis gagal ditolak. Dengan demikian, peserta didik field independent memperlihatkan hasil kemampuan komunikasi matematis yang lebih baik dari pada peserta didik yang field dependent.

Pada prestasi belajar terjadi hal sebaliknya, diperoleh $\mathrm{t}_{\text {hitung }}=4,75279>\mathrm{t}_{\text {tabel }}=2,27338$ artinya hipotesis null $\left(\mathrm{H}_{03}\right)$ signifikan atau hipotesis ditolak. Dengan kata lain, peserta didik yang berprestasi tinggi menunjukkan hasil kemampuan representasi matematis yang lebih baik dari pada peserta didik yang berprestasi rendah.

Pada kemampuan komunikasi diperoleh $\mathrm{t}_{\text {hitung }}=3,83782>\mathrm{t}_{\text {tabel }}=2,27338$ artinya hipotesis null $\left(\mathrm{H}_{04}\right)$ signifikan atau hipotesis ditolak. Peserta didik yang berprestasi tinggi menunjukkan hasil kemampuan komunikasi matematis 
yang lebih baik dari pada peserta didik yang berprestasi rendah.

\section{SIMPULAN DAN SARAN}

\section{Simpulan}

Simpulan yang dapat ditarik dari hasil penelitian ini adalah (1) tidak terdapat interaksi gaya kognitif dan prestasi belajar dalam mempengaruhi kemampuan representasi dan komunikasi matematis, (2) terdapat perbedaan pada peserta didik yang bergaya kognitif field dependent dan perserta didik field independent ditinjau dari kemampuan representasi matematis. Hasil penelitian menunjukkan peserta didik field independent mempunyai kemampuan yang lebih baik dalam representasi matematis, (3) terdapat perbedaan pada peserta didik yang bergaya kognitif field dependent dan perserta didik field independent ditinjau dari kemampuan komunikasi matematis. Hasil penelitian menunjukkan peserta didik field independent mempunyai kemampuan yang lebih baik dalam komunikasi matematis, (4) terdapat perbedaan pada peserta didik yang berprestasi tinggi, sedang, dan rendah dalam berkemampuan representasi dan komunikasi. Hasil penelitian menunjukkan peserta didik yang berprestasi tinggi mempunyai kemampuan representasi dan komunikasi lebih baik dari peserta didik yang berprestasi sedang dan rendah.

\section{Saran}

Berdasarkan hasil serta temuan penelitian, dan dengan memeperhatikan keterbatasan penelitian, saran yang dapat disampaikan adalah sebagai berikut: (1) disarankankan kepada guru untuk meningkatkan kemampuan representasi dan komunikasi matematis di kelas dengan pembelajaran yang lebih mengkaktifkan peserta didik untuk menulis, membaca, dan mempraktekkan pekerjaan selama di kelas sehingga melatih peserta didik untuk meningkatkan representasi dan komunikasi matematis. (2) disarankan kepada guru untuk peserta didik yang berprestasi baik sebaiknya diberdayakan dengan membimbing peserta didik tersebut menjadi tutor sebaya bagi teman-temannya yang lain. Selain meningkatkan kemampuan bagi peserta didik tersebut juga bagi peserta didik yang lain mempunyai cara sendiri dalam menyampaikan argumen bersama teman-temannya. (3) disarankan kepada guru untuk melakukan pendekatan secara individual terhadap peserta didik yang bergaya kognitif field dependent.
Sebaikanya peserta didik ini leibih dibimbing dalam menganalisis informasi baik pada bahan ajar ataupun pada soal dan mengkomunikasikan secar lebih runtun dan logis. Cara berpikirnya yang lebih meluas dan kurang dapat membagi bagian-bagian materi menjadi lebih rinci atau kurang teliti. Dalam menginterpretasikan ide matematis dapat memahami masalah secara keseluruhan dan menyatakan langkah dengan mocoba-coba dan pernyataan masih bersifat umum, terkadang respon secara lisan masih kurang jelas. (4) disarankan kepada guru untuk peserta didik yang bergaya kognitif field independent untuk memperhatikan sosialisasi dengan teman-temannya, lebih dibimbing dalam mempertahankan argumen, dan dikembangkan kemampuan komunikasi ide-ide matematika secara lisan. Karena pada umumnya mereka lebih mendengarkan pendapat sendiri tetapi peserta didik ini lebih analitis dan kritis dalam memperoleh materi ajar. (5) disarankan kepada para peneliti lain, apabila ingin melakukan penelitian yang sejenis sebaiknya tunjukkan kompetensi lain dalam meningkatkan kemampuan representasi dan komunikasi seperti aljabar, statistika, dan bidang sosial. Kemudian untuk melihat perbedaan peserta didik pada gaya kognitifnya dapat dilihat kemampuan matematis lain selain representasi dan komunikasi matematis, seperti kemampuan koneksi, kemampuan penalaran, dan kemampuan pemecahan masalah.

\section{DAFTAR PUSTAKA}

Ardana, I. M. (2008). Peningkatan kualitas belajar siswa melalui pengembangan pembelajaran matematika berorientasi gaya kognitif dan berwawasan konstruktivis. Salatiga: Jurusan Pendidikan Matematika FMIPA UNDIKSYA.

Azwar, S. (1996). Tes prestasi fungsi dan pengembangan pengukuran prestasi belajar. Yogyakarta: Pustaka belajar.

Direktorat Pembinaan SMA. (2010). Juknis penyusunan penilaian afektif di SMA. Jakarta: Direktorat Pembinaan SMA.

Goldin, G. (2002). Representation in mathematical learning and problem solving. Handbook of International Research in Mathematics Education. Rutgers University, pp. 197-216.

Hwang, W. Y., et al. (2007). Multiple representation skills and creativity effects on mathematical problem solving using a 
multimedia whiteboard system. Educational Technology \& Society, 10(2), 191-212.

Glass, G. V \& Hopkins, K. D. (1984). Statistical methods in education and psychologu $\left(2^{\text {nd }}\right)$. Englewood Cliffs NJ: Prentice-Hall.

Goldin, G. (2002). Representation in mathematical learning and problem solving. Dalam L. D. English. Handbook Education (197-216). New York, NY: Lawrence Erlbaum Associates.

Ibrahim, M, et al. (2004). Relationship between cognitive thinking and chemistry achievement among form four science students. Disertasi doktor, tidak diterbitkan, Universitas Teknologi malaysia, Malaysia.

Hernawati, F. (2016). Pengembangan perangkat pembelajaran matematika dengan pendekatan PMRI berorientasi pada kemampuan representasi matematis. Jurnal Riset Pendidikan Matematika, 3(1), 34-44. doi:http://dx.doi.org/10.21831/jrpm.v3i1. 9685.

Huggins, B. \& Maiste, T. (1999). Communication in Mathematics. Master's Action Research Project, St Xavier University \& IRI/Skylight.

Hwang, W. Y., et al. (2007). Multiple representation skills and creativity effects on mathematical problem solving using a multimedia whiteboard system. Educational Technology \& Society, 10(2), 191-212.

Ibrahim, M, et al. (2004). Relationship between cognitive thinking and chemistry achievement among form four science students. Disertasi doktor, tidak diterbitkan, Universitas Teknologi malaysia, Malaysia.

Janvier, C. (1987). Problems of representation in the teaaching and learning of mathematics. Hilldale, NJ: Lawrence Erlbaum Associates.

Johson, R. A \& Wichern, D. W. (2007). Applied multivariate statistical analysis. Upper Saddle River, NJ: Pearson Prentice Hall.

Kalathil, R. R. \& Sherin, M. G. (2000). Role of students' representations in the mathematics classroom. Dalam B. Fihman \& S. O'Cornnor-Divelbiss (Eds.),
Fourth International Conference of Learning Sience (pp. 27-28). Mahwah, NJ: Erlbaum.

Moschovich, J. N. (2010). Language and mathematics eduation. California: Information Age Publishing.

Mendikbud. (2012). Revisi rencana strategies direktorat jendral pendidikan menengah (renstra ditjen dikmen) 2010-2014. Jakarta: Kementerian Pendidikan dan Kebudayaan.

Moschovich, J. N. (2010). Language and Mathematics education: Multiple persepectives and directions for research Charlotte. NC: Information Age Publishing.

NCTM. (2000). Principles and standards for school mathematics. Reston, VA: Ntional Council of Teachers of Mathematics Inc.

Oh, E. \& Lim, D. (2005). Cross relationship between cognitive style and learner variabels in online learning environment. Journal of Interactibe Online Learning 4(1). 53-66.

Riding, R \& Rayner, S.. (1998). Cognitive style and learning strategies understanding style differences in learning and behaviour. London, UK: David Fulton Publishers.

Ruttun, R. D. (2011). The effect of individual differencesand instructional aids on learners' disorientation, learning performance and attitude in a hypermedia learning system. Brunei: Computing and Mathematics Brunei University.

Saracho, O. N. (1997). Teachers' and student' cognitive styles in early childhood education. London, UK: Bergin \& Garvey.

Steven, J. P. (2009). Applied multivariate statistics for the scocial sciences. New York, NY: Routledge.

Sukoco, H., \& Mahmudi, A. (2016). Pengaruh pendekatan brain-based learning terhadap kemampuan komunikasi matematis dan self-efficacy siswa SMA. PYTHAGORAS: Jurnal Pendidikan Matematika, 11(1), 1124.

doi:http://dx.doi.org/10.21831/pg.v11i1.9 678

Tandiling, E. (2012). Pengembangan instrumen untuk mengukur kemampuan komunikasi 
Pythagoras, 11 (2), Desember 2016 - 206

Ranisa Junita

matematik, pemahaman matematik, dan self regulated learning peserta didik dalam pembelajaran matematika di sekolah menengah atas. Jurnal Penelitian Pendidikan Vol. 13(1), 24-31.

Tjalla, A. (2011). Potret mutu pendidikan Indonesia ditinjau dari hasil-hasil studi internasional. Jakarta: Universitas Negeri Jakarta.

Watson, A. (2006). Raising achievement of secondary mathematics. New York, NY: Open University Press. 